\title{
Fatty Acid Profile of Microalgal Oils as a Criterion for Selection of the Best Feedstock for Biodiesel Production
}

\author{
Małgorzata Hawrot-Paw ${ }^{1, *(\mathbb{D})}$, Patryk Ratomski ${ }^{1} \mathbb{D}$, Adam Koniuszy $^{1}\left(\mathbb{D}\right.$, Wojciech Golimowski ${ }^{2} \mathbb{D}^{\mathbb{D}}$, \\ Mirosława Teleszko ${ }^{3}$ and Anna Grygier ${ }^{4}$ (D)
}

1 Department of Renewable Energy Engineering, Faculty of Environmental Management and Agriculture, West Pomeranian University of Technology in Szczecin, Pawla VI 1, 71-459 Szczecin, Poland; patryk.ratomski@zut.edu.pl (P.R.); adam.koniuszy@zut.edu.pl (A.K.)

2 Department of Agroengineering and Quality Analysis, Faculty of Engineering and Economics, Wroclaw University of Economics and Business, Komandorska 180/120, 53-345 Wroclaw, Poland; wojciech.golimowski@ue.wroc.pl

3 Department of Food Technology and Nutrition, Faculty of Production Engineering, Wroclaw University of Economics and Business, Komandorska 118/120, 53-345 Wrocław, Poland; miroslawa.teleszko@ue.wroc.pl

4 Department of Food Technology of Plant Origin, Faculty of Food Science and Nutrition, Poznań University of Life Sciences, Wojska Polskiego 31, 60-624 Poznań, Poland; anna.grygier@up.poznan.pl

* Correspondence: malgorzata.hawrot-paw@zut.edu.pl

Citation: Hawrot-Paw, M.; Ratomski, P.; Koniuszy, A.; Golimowski, W.;

Teleszko, M.; Grygier, A. Fatty Acid Profile of Microalgal Oils as a Criterion for Selection of the Best Feedstock for Biodiesel Production. Energies 2021, 14, 7334. https:// doi.org/10.3390/en14217334

Academic Editor: Rocio Maceiras

Received: 30 September 2021

Accepted: 2 November 2021

Published: 4 November 2021

Publisher's Note: MDPI stays neutral with regard to jurisdictional claims in published maps and institutional affiliations.

Copyright: (C) 2021 by the authors. Licensee MDPI, Basel, Switzerland. This article is an open access article distributed under the terms and conditions of the Creative Commons Attribution (CC BY) license (https:// creativecommons.org/licenses/by/ $4.0 /)$.

\begin{abstract}
Microalgae are considered to be potentially attractive feedstocks for biodiesel production, mainly due to their fast growth rate and high oil content accumulated in their cells. In this study, the suitability for biofuel production was tested for Chlorella vulgaris, Chlorella fusca, Oocystis submarina, and Monoraphidium strain. The effect of nutrient limitation on microalgae biomass growth, lipid accumulation, ash content, fatty acid profile, and selected physico-chemical parameters of algal biodiesel were analysed. The study was carried out in vertical tubular photobioreactors of $100 \mathrm{~L}$ capacity. The highest biomass content at $100 \%$ medium dose was found for Monoraphidium $525 \pm 29 \mathrm{mg} \cdot \mathrm{L}^{-1}$. A $50 \%$ reduction of nutrients in the culture medium decreased the biomass content by $23 \%$ for $O$. submarina, 19\% for Monoraphidium, 13\% for C. vulgaris and $9 \%$ for C. fusca strain. Nutrient limitation increased lipid production and reduced ash content in microalgal cells. The highest values were observed for Oocystis submarina, with a $90 \%$ increase in lipids and a $45 \%$ decrease in ash content in the biomass under stress conditions. The fatty acid profile of particular microalgae strains was dominated by palmitic, oleic, linoleic, and linoleic acids. Nutrient stress increased the amount of saturated and unsaturated fatty acids affecting the quality of biodiesel, but this was determined by the type of strain.
\end{abstract}

Keywords: microalgae; biomass; lipid; fatty acid profile; biodiesel; nutrient limitation; stress conditions

\section{Introduction}

In the transport sector, biofuels are an alternative to fossil fuels, which are environmentally harmful [1]. Increasing attention on biofuels and technologies of their production was also caused by the global fuel crisis [2].

According to the type of feedstock used in production, there are three main generations of biofuels [3]. The first and second generations of biofuels use food crops, oil crops, and plant biomass from non-food crops and from forestry as substrates. Therefore, their use is related to high competition of plant production and area of arable land [4]. A feasible alternative are third-generation biofuels derived from algal biomass [5].

Microalgal biomass contains considerable amounts of molecules suitable for biofuel production, but also for food supplements, fertilisers, pigments, etc. [6,7]. The potential for energetic use of microalgae is very high, e.g., for the production of biogas, bioethanol, bio- 
hydrogen, bio-oil or biodiesel [8,9] currently produced mainly from soybean oil, rapeseed oil, sunflower oil, palm oil [10].

Microalgae are promising candidates for industrial production. Their cultivation does not compete with food crop production and can be carried out using not only freshwater, but also salt water, saline water and different kinds of wastewater [11,12]. Compared to plants, they are characterised by a high photosynthetic rate [13]. Under suitable conditions, their growth rate and the yield of biomass are higher than those of terrestrial plants [14]. The yield of microalgal oil is several times higher than the best oil producing crop [15].

Although algal biofuels have many advantages, they have still not been commercialised. A significant barrier is the excessively high production costs compared to fossil fuels [16], including the production of biomass, its dewatering and the extraction of valuable cellular components [6]. These components include proteins, carbohydrates and lipids [17]. Microalgal oil is a good feedstock for biodiesel production [18], but its content in biomass is often not sufficient for industrial application [19]. There are species of microalgae that accumulate large amounts of lipids, but their growth rate is generally very slow [20]. The lipid content varies according to species of microalgae and culture conditions [21]. Average values range from $20 \%$ to $70 \%$ of the cell dry weight [22,23]. There are some strategies to increase the natural lipid content in algal cells. This can be realised by genetic engineering [24] or by modifying growing conditions by changing light intensity [25], carbon dioxide content [26], low temperature [27], high light intensity [28], high salt and iron concentrations in the culture medium [29,30], salinity levels [31] or limiting nutrient availability [32]. Microalgae for biofuel production should be characterised by a high cellular lipid accumulation capacity [33]. The application of suitable species will have a beneficial effect on the cost-effectiveness of biofuel production [34].

When assessing the potential of microalgae for biodiesel production, not only the amount of lipids in their cells is important, but also the content of the relevant fatty acids (FAs) [22] as direct precursors for third-generation biofuel production. The fatty acid profile of biodiesel is identical to the profile of the oil used in their production [35]. The increase in lipid content is determined by changes in biosynthetic pathways leading to the formation and accumulation of lipids mainly as a triacylglycerol (TGA) [36]. Microalgal lipids can be divided into neutral lipids, including saturated (SFA) and monounsaturated fatty acids (MUFA), representing the main fatty acids in triacylglycerols, and polyunsaturated fatty acids (PUFA) enriched in polar lipids [37]. The fatty acid profile (FA) of microalgae may also include iso- and anteiso-branched FAs, methyl-branched FAs, 3-Hydroxy and amide FAs [38].

Triacylglycerols can be converted to fatty acid methyl esters by a transesterification process [39]. In this process the fatty acid composition of the feedstock is not changed [40]. The content of each FAs group in the oil is significant for the quality of the biofuel [22], therefore knowledge of the FA profile can be useful in the selection of algae species for fuel applications. As well as the lipid content, the fatty acid composition can also be modified by changing the concentration of carbon dioxide [41] or by nitrogen $(\mathrm{N})$ deficiency [42].

The most important features determining the suitability of a feedstock for biofuel production are its energy properties and parameters indicating the quality of engine combustion [43]. For biodiesel, these are the heating value (HHV) and the cetane number (CN). In addition, the rheological parameters of biodiesel such as density (D) and kinematic viscosity $(\mathrm{KV})$ are very important, as they have a direct impact on the injection of the fuel inside combustion chamber of the engine [44,45]. Moreover, these parameters affect the functioning of the diesel engine fuel feed system, especially the fuel filter at low temperatures, resulting in flow blockage, which is characterised by a cold filter plugging point (CFPP) [46]. During storage of biofuels, their stability is also very significant, as expressed by the parameters of oxidation stability (OS) and iodine number (IV) [47].

Our aim was to investigate the effect of stress induced by nutrient deprivation on microalgal biomass and lipid production and fatty acid profile (FA). This study was carried 
out at technical scale. In addition, FAs were used to predict biodiesel properties and evaluate the suitability of microalgae for biofuel production.

\section{Materials and Methods}

\subsection{Microalgae Strains}

Microalgae strains of Chlorella vulgaris, Chlorella fusca, Oocystis submarina and Monoraphidium were obtained from the Culture Collection of Baltic Algae (University of Gdańsk, Gdańsk, Poland). The inocula were stored in liquid medium F/2 [48] containing $\left[\mathrm{g} \cdot \mathrm{L}^{-1}\right.$ ]: $\mathrm{NaNO}_{3}-0.075 \mathrm{~g} ; \mathrm{NaH}_{2} \mathrm{PO}_{4} \cdot 2 \mathrm{H}_{2} \mathrm{O}-0.00565 \mathrm{~g}$; stock solution of trace elements- $1 \mathrm{~mL} \cdot \mathrm{L}^{-1}$ $\left(\mathrm{Na}_{2}\right.$ EDTA $4.16 \mathrm{~g}, \mathrm{FeCl}_{3} 6 \mathrm{H}_{2} \mathrm{O} 3.15 \mathrm{~g}$, $\mathrm{CuSO}_{4} 5 \mathrm{H}_{2} \mathrm{O} 0.01 \mathrm{~g}$, $\mathrm{ZnSO}_{4} 7 \mathrm{H}_{2} \mathrm{O} 0.022 \mathrm{~g}, \mathrm{CoCl}_{2}$ $6 \mathrm{H}_{2} \mathrm{O} 0.01 \mathrm{~g}, \mathrm{MnCl}_{2} 4 \mathrm{H}_{2} \mathrm{O} 0.18 \mathrm{~g}$ and $\mathrm{NaMoO}_{4} 2 \mathrm{H}_{2} \mathrm{O} 0.18 \mathrm{~g}$ ) and stock solution of vitamin mix-1 $\mathrm{mL} \cdot \mathrm{L}^{-1}$ (cyanocobalamin (vitamin B12) $0.0005 \mathrm{~g}$, thiamine $\mathrm{HCl}$ (vitamin B1) $0.1 \mathrm{~g}$, biotin $0.0005 \mathrm{~g})$. Microalgae were stored at $4{ }^{\circ} \mathrm{C}$, with lighting $(12 / 12 \mathrm{~h} \mathrm{light} /$ dark cycle).

\subsection{Experimental Setup}

Microalgae cultures were carried out in vertical tubular photobioreactors with a total volume of $100 \mathrm{~L}$, with $70 \mathrm{~L}$ of growth medium. Microalgae were cultured in F/2 culture medium containing all required components at full dose (100\%) or reduced by half (50\%). A $20 \mathrm{~L}$ of 7-day microalgal inoculum was introduced into particular photobioreactors.

The culture was illuminated by light emitting diode (LED light with white, red and blue diodes) under 18/6 h light/dark cycle. Algae culture was mixed and aerated by 175 W membrane pump (HAILEA ACO-500A, Raoping, China) with a capacity of $275 \mathrm{~L} \cdot \mathrm{min}^{-1}$. The experiment was carried out as a batch culture for 10 days.

\subsection{Analytical Methods}

\subsubsection{Biomass Content Determination}

Biomass content was determined by thermogravimetric measurement using a weighdryer (AXIS ATS60, Gdańsk, Poland) [49]. The results were recalculated and presented in $\mathrm{mg} \cdot \mathrm{L}^{-1}$. Measurement was carried out on the last day of the experiment.

\subsubsection{Lipid and Ash Content of Biomass}

Lipid content in biomass was determined by the gravimetric method. To extract lipids from microalgal cell, a modified Bligh and Dyer method was applied [50]. Total lipids were determined after evaporation of the solvent. The lipid content was determined according to the following formula:

$$
\mathrm{LC}=\left(\frac{\mathrm{m}_{\mathrm{L}}}{\mathrm{m}_{\mathrm{DAB}}}\right) \cdot 100
$$

where: $\mathrm{m}_{\mathrm{L}}$ is the mass of lipids $(\mathrm{g})$ and $\mathrm{m}_{\mathrm{DAB}}$ is the dry microalgal biomass $(\mathrm{g})$.

The ash content in biomass was determined gravimetrically according to the Standard PN-EN ISO 18122:2016-01 [51].

\subsection{Fatty Acids Methyl Esters Analysis}

Lipid extraction from microalgae biomass was performed using the method of Folch et al. [52]. For the determination of fatty acids, they were converted into fatty acid methyl esters according to the method of AOCS Ce 2-66 [53].

The fatty acid composition of the studied samples was estimated using gas chromatography (GC). Fatty acid methyl esters were separated using a Trace 1300 (Thermo Scientific, Waltham, MA, USA) gas chromatography system equipped with a SP TM-2560 capillary column $(100 \mathrm{~m} \times 0.25 \mathrm{~mm} \times 0.2 \mu \mathrm{m})$ (Supelco, Bellefonte, PA, USA) and a flame-ionization detector (FID). Column temperature was held at $160^{\circ} \mathrm{C}$ for $1 \mathrm{~min}$, then the temperature was increased from $160{ }^{\circ} \mathrm{C}$ to $220^{\circ} \mathrm{C}$ at $6{ }^{\circ} \mathrm{C} / \mathrm{min}$ and held at $220^{\circ} \mathrm{C}$ for an additional $35 \mathrm{~min}$. The temperature of the injection port and the detector was set at $240^{\circ} \mathrm{C}$. Hydrogen was used as a carrier gas at a flow rate of $1.5 \mathrm{~mL} / \mathrm{min}$. The results were expressed as a percentage of the total peak area of all the fatty acids in microalgae lipid extract sample. 
The peaks were identified by comparing the retention times with those of a mixture of external standard methyl esters (Supelco 37 FAME Mix C 4-C 24 Component, SigmaAldrich, St. Louis, MO, USA).

\subsection{Biodiesel Properties According to Fatty Acid Profile}

Analysis of selected biofuel properties was carried out using the BiodieselAnalyzer@ software (version 2.2, BRTeam, Karaj, Iran), according to the methodology described in the works of Ramírez-Verduzco et al. [54] and Talebi et al. [55]. This software was designed to evaluate (predict) the biodiesel fuel properties based on the fatty acid profile determined by gas chromatography, therefore eliminate long and expensive laboratory tests.

Difficulties to determine the best feedstock for biodiesel production arise from the presence more than one evaluation criteria. Therefore, the multi-criteria decision problem required several mathematical programming models. The PROMETHEE method is one of such tools. According to the references [54-57], seven functional parameters were selected and associated with weight factors. The highest weight was assigned to the calorific value $(\mathrm{HHV}=0.5)$, followed by the cetane number $(\mathrm{CN}=0.2)$. The weighting coefficients for CFPP, D, KV, OS, and IV were the same and equals 0.06 .

\subsection{Statistical Analysis}

All analyses were carried out in triplicate. Results were statistically analysed using Statistica software (version 13.3, 2016; Dell Inc., Tulsa, OK, USA). Two-factor analysis of variance was used. The significance of differences between means was assessed using Tukey's test at $p \leq 0.05$. The standard deviation (SD) was also determined.

\section{Results and Discussion}

\subsection{Algal Biomass Concentration}

The biomass content in the particular photobioreactors was presented in Figure 1. Higher values were observed at the $100 \%$ dose of nutrient solution. The biomass content ranged from $292 \pm 14 \mathrm{mg} \cdot \mathrm{L}^{-1}$ for $C$. fusca to $525 \pm 29 \mathrm{mg} \cdot \mathrm{L}^{-1}$ for Monoraphidium. These values correspond with results available in the literature [58]. Biomass production can be increased using nutrient-rich culture media [59] but the results are not always positive. In a study carried out by Sacristán et al. [60], increase in nutrient content in culture medium had a negative impact on the growth and development of Scenedesmus acutus. This could be associated with the high $\mathrm{pH}$ in the culture medium and the presence of toxins in the wastewater used in the cultivation.

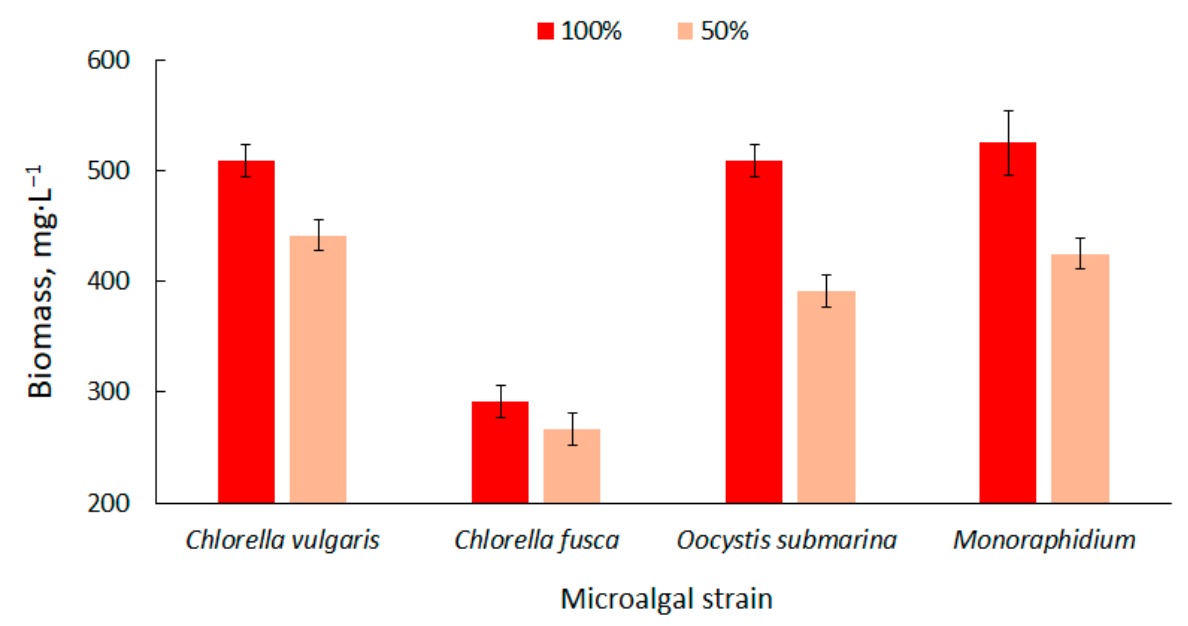

Figure 1. Dynamics of biomass content changes of four strains in relation to nutrient supply in the culture medium. 
Nutrient limitation decreases the productivity of biomass [61] which is confirmed by the results of the present study. The amount of biomass decreased by more than $20 \%$ for $O$. submarina, 19\% for Monoraphidium, 13\% for C. vulgaris and 9\% for C. fusca. Kim et al. [62] cultivated strains of Chlorella sp., Dunaliella salina and Dunaliella sp. and found that the appropriate amount of nutrients in the medium determines the effective production of algal biomass. They observed a higher increase in biomass in a culture medium with a higher nutrient content.

\subsection{Lipid Accumulation under Nutrient Limitation Conditions}

High lipid content in microalgae cells is one of the most important criteria that determines their potential use for biofuel production [63]. The lipid content for the tested microalgae strains is shown in Figure 2. The average amount of lipids in relation to dry matter, at the complete nutrient dose $(100 \%)$, ranged from $12.33 \pm 1.0$ for 0 . submarina to $13.53 \pm 2.1 \%$ for C. fusca. A higher lipid content for O. submarina was reported by Klin et al. [64], but increase in lipid accumulation could be associated with using a different culture medium and a significantly lower photobioreactor capacity.

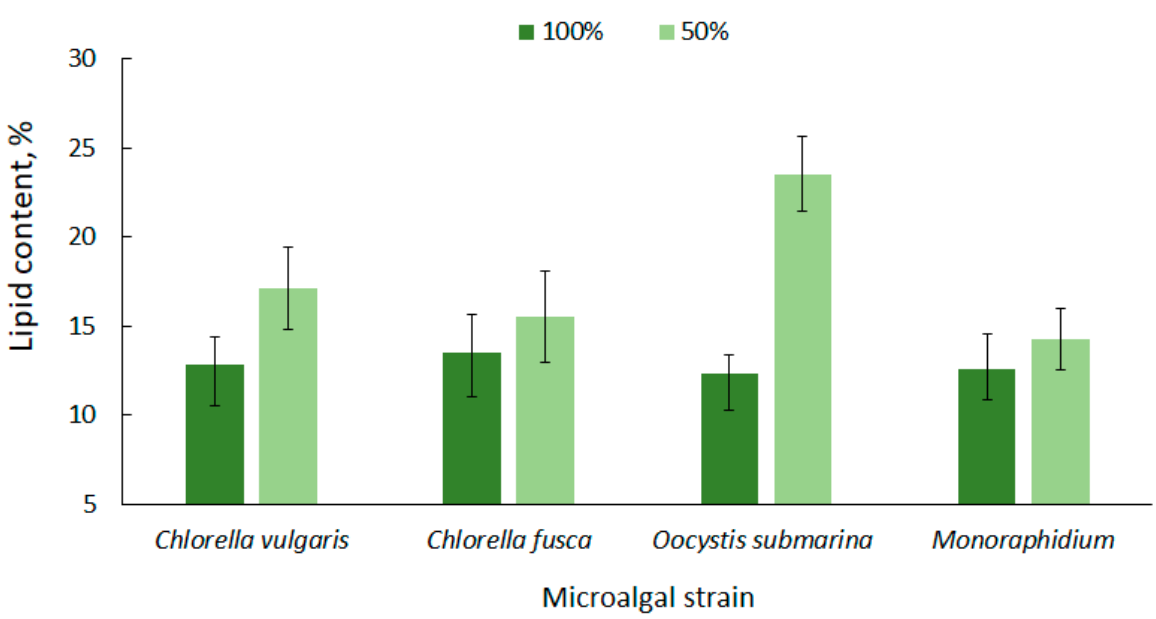

Figure 2. Lipid content in microalgal biomass under nutrient limitation.

Under nutrient stress treatment (50\% F/2), there was a $14 \%$ increase in lipid accumulation for Monoraphidium, 15\% for C. fusca, 31\% for C. vulgaris, and over 90\% dla $O$. submarina; however, only the $C$. vulgaris and $O$. submarina increase was statistically significant. Nutrient limitation to promote lipid accumulation in microalgal cells is a commonly used method [65,66]. Results presented by Converti et al. [67] confirmed the correlation between nitrogen depletion in the culture medium and an increase in lipid accumulation for Nannochloropsis oculata and C. vulgaris. A 75\% nitrogen limitation resulted in a two-fold increase of lipids in the algal cells. In the present study, a slightly lower lipid content was observed for C. fusca (from $13.53 \pm 2.1 \%$ to $15.53 \pm 2.5 \%$ ) and for Monoraphidium (from $12.53 \pm 2.0 \%$ to $14.27 \pm 1.7 \%$ ), while for $O$. submarina the lipid content under stress conditions was $23.53 \%$. \pm 2.1 A similar correlation was observed in a previous study [68] evaluating nutrient stress caused by nitrogen limitation in wastewater from salmon aquaculture on lipid content in C. vulgaris biomass. The highest value $(11.81 \%)$ was determined at the lowest dose of aquaculture wastewater. In the present study, the lipid content in biomass of $\mathrm{C}$. vulgaris, regardless of nutrient conditions, was in a range corresponding to values for this species reported by other authors $[69,70]$.

\subsection{Ash Content}

Microalgal biomass has a high ash content compared to terrestrial plant biomass, and this is one of the major disadvantages in algae conversion to fuel [71]. The ash content in dry matter, depending on the microalgal strain and the culture conditions, is up to $43 \%$ [72]. 
This reduces the total volatile solids content of the feedstock, one of the most important parameters determining the quality of biofuel. A lot of final ash in algal biomass would require fuel purification $[73,74]$.

According to the strain, the average ash content in biomass at $100 \%$ dose was in the range from $19.74 \pm 1.70$ for O. submarina) to $43.19 \pm 0.24 \%$ for Monoraphidium (Figure 3). Similar results were presented by $\mathrm{Bi}$ and $\mathrm{He}$ [75] who found up to $19 \%$ ash content for green algae. In this study, the results show that nutrient stress not only promotes lipid accumulation, but generally causes a decrease in ash content in microalgal biomass. In the nutrient-limited medium (50\%), ash content ranged from $11.16 \pm 0.07 \%$ for 0 . submarina to $37.04 \pm 0.38 \%$ for Monoraphidium. Increase in ash content was observed only for C. fusca, but it was statistically insignificant difference. The correlation between nutrient content and ash content in microalgal biomass was also reported by Roostaei et al. [76]. The limited availability of nutrients in Chlorella vulgaris culture significantly decreased ash content.

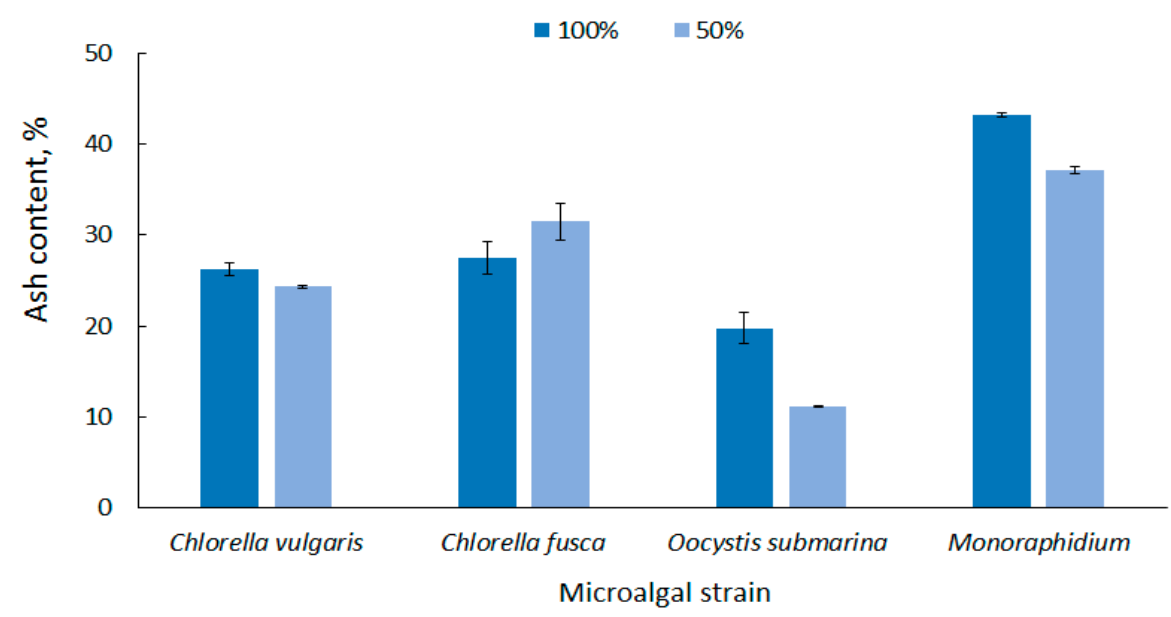

Figure 3. Ash content in microalgal biomass under nutrient limitation.

\subsection{Fatty Acid Composition and Content}

Microalgal oil is a source of saturated and unsaturated fatty acids [38]. In FAs profiles, groups with chain lengths of C16-C18 are most commonly determined [77], as also confirmed by the results of the presented study (Table 1, Figure 4A-D). The most important FAs that determine the quality of the biofuel are palmitic acid (C16:0), stearic acid (C18:0), oleic acid (C18:1), linoleic acid (C18:2) and linolenic acid (C18:3) [78]. In microalgal biomass cultivated in culture medium with complete suggested nutrient rate $(100 \% \mathrm{~F} / 2)$, palmitic acid (16:0), oleic acid (18:1), linoleic acid (18:2) and linolenic acid (C18:3 n-3) were dominant in the profile, but in different quantities for each strain. Due to environmental stress, fatty acid composition changes [79] which was also observed in this study. A 50\% reduction of the dose for all medium components increased palmitic acid content for all strains, oleic acid content for C. fusca and O. submarina, and linoleic acid for C. vulgaris and C. fusca. Furthermore, acids that were not present in the 100\% F/2 dose were determined, e.g., C16:1, C18:0, C18:3 n-6 and C18:4 for Monoraphidium. A higher content of saturated fatty acids (C16:0, C18:0) increases the cetane number (CN) [80]. FAs profiles change not only with species but also intraspecies [81]. Petkov and Garcia [82] analysed the fatty acid composition of three Chlorella strains, including freshwater and marine strains, and found that species belonging to the same genus contained the same acids but in different ratios. The presented study does not confirm these results. The C16:1 and C18:3 n- 6 fatty acids determined in the FAs profile of $C$. vulgaris were not found in $C$. fusca. The change in FAs composition may also result from different cultivation methods (photoautotrophic, heterotrophic) [83] or from a change in cultivation conditions. In a study carried out by Yusof et al. [41], increasing amount of carbon dioxide in C. vulgaris culture medium from 1 to $10 \%$ increased concentrations of palmitic, oleic, linoleic, and linolenic acids. In the 
present study, cultivations of all strains were carried out at one test site, at the same time, with uniformity of all growing parameters. This means that a biological factor, directly associated with the metabolic activity of particular microalgal strains, is essential for the observed changes. Analysis of FAs profiles in relation to growth stage and adjusting biomass harvesting to the most beneficial stage for optimal fatty acid composition may be important [81]. In a study carried out by da Costa et al. [84], growth phase induced more changes in the fatty acid profile of Tisochrysis lutea than stress associated with $\mathrm{N}$ limitation in culture medium.

Table 1. Fatty acid profile of microalgae biomass.

\begin{tabular}{|c|c|c|c|c|c|c|c|c|}
\hline \multirow{2}{*}{ Fatty Acid (m:n *) } & \multicolumn{2}{|c|}{ Chlorella vulgaris } & \multicolumn{2}{|c|}{ Chlorella fusca } & \multicolumn{2}{|c|}{ Oocystis submarina } & \multicolumn{2}{|c|}{ Monoraphidium } \\
\hline & $100 \%$ & $50 \%$ & $100 \%$ & $50 \%$ & $100 \%$ & $50 \%$ & $100 \%$ & $50 \%$ \\
\hline C16:0 & 20.73 & 24.61 & 25.53 & 28.63 & 17.17 & 26.35 & 19.01 & 19.56 \\
\hline C16:1 & 1.46 & 1.46 & ta $* *$ & ta $* *$ & ta $* *$ & $\mathrm{ta}^{* *}$ & ta $* *$ & 2.52 \\
\hline C18:0 & 6.59 & 5.39 & 3.11 & ta $* *$ & ta $* *$ & ta $* *$ & ta $* *$ & 0.72 \\
\hline $\mathrm{C} 18: 1 \mathrm{cis}$ & 22.72 & 21.68 & 18.50 & 20.23 & 10.15 & 19.95 & 17.63 & 13.62 \\
\hline $\mathrm{C} 18: 2 \mathrm{cis}$ & 9.90 & 10.41 & 11.20 & 12.10 & 16.98 & 11.74 & 22.51 & 19.37 \\
\hline C18:3 n-6 & 1.98 & 2.37 & $\mathrm{ta}^{* *}$ & ta $* *$ & ta $* *$ & $\mathrm{ta}^{* *}$ & ta $* *$ & 1.09 \\
\hline $\mathrm{C} 18: 3 \mathrm{n}-3$ & 22.96 & 18.11 & 25.32 & 23.84 & 28.00 & 22.91 & 17.53 & 16.29 \\
\hline C18:4 & 3.87 & 3.68 & 3.76 & ta $* *$ & 2.77 & 2.99 & ta $* *$ & 7.91 \\
\hline
\end{tabular}

* $\mathrm{m}: \mathrm{n}$ ratio in FAs description denotes $\mathrm{m}$ carbon atoms and $\mathrm{n}$ double bonds between carbon atoms, ${ }^{* *}$ ta—trace amounts.

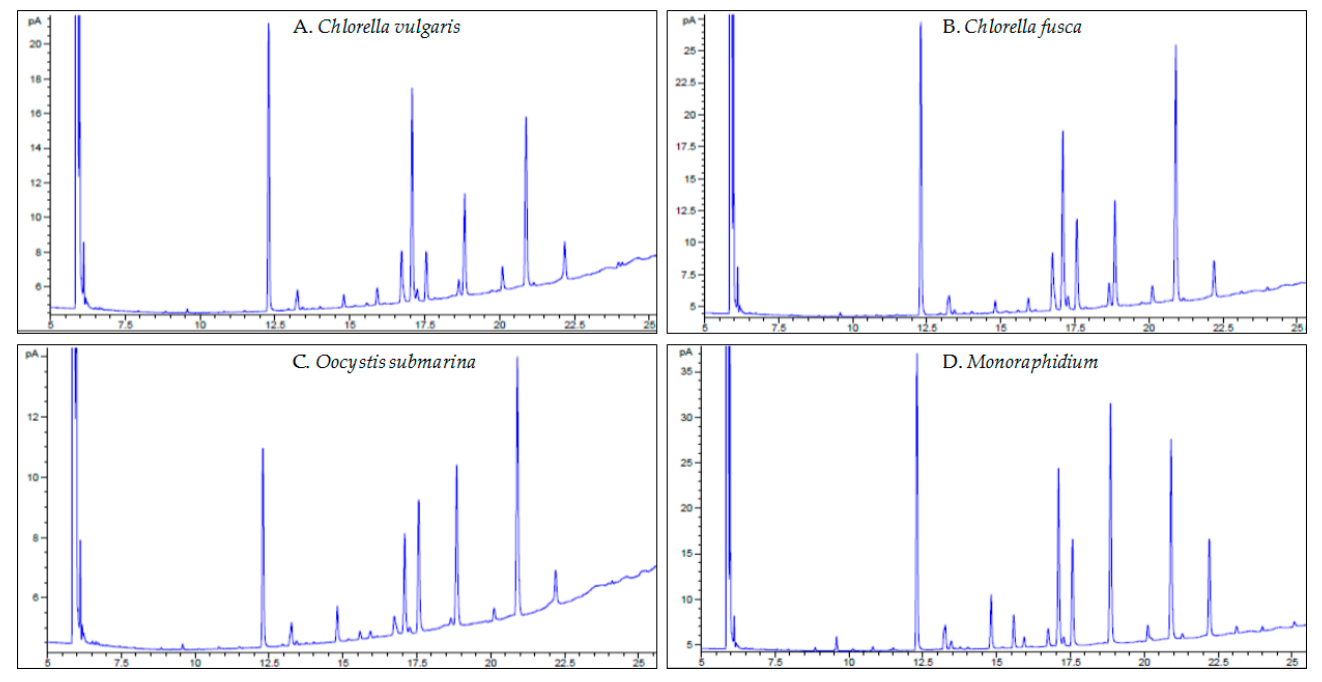

Figure 4. GC-FID chromatograms of fatty acids from particular microalgal strain.

The content of particular fatty acid categories is important for the quality of the biodiesel fuel. High concentration of saturated fatty acids (SFAs) ensures good oxidation resistance for biofuel [85]. In the presented study C. vulgaris has a total of $27.32 \% \mathrm{SFAs}, \mathrm{C}$. fusca of $28.64 \%$, O. submarina of $17.17 \%$, and Monoraphidium of $19.01 \%$ (Figure 5). Taking into account not only oxidation stability, but also liquidity at low temperatures, monounsaturated fatty acids (MUFAs) are particularly important for biodiesel production [86]. The MUFAs content in the presented studies ranged from $10.15 \%$ to $24.18 \%$ of the total lipid composition. The lowest content was found for O. submarina, the highest for $C$. vulgaris $(100 \%)$. Dahmen et al. [87] applied stress conditions (high salinity) to Picochlorum culture and observed lipid enrichment in saturated fatty acids. Nutrient stress from nutrient limitation $(50 \% \mathrm{~F} / 2)$ increased SFAs content to $30 \%$ for C. vulgaris, $26.35 \%$ for O. submarina, and slightly for Monoraphidium (to 20.28\%). Arora and Philippidis [88] reported beneficial for biofuel production biosynthesis of SFAs and MUFAs in C. vulgaris culture using sweet sorghum pomace hydrolysate (mixotrophic conditions). Rohit and Mohan [89] under mixotrophic and heterotrophic conditions, found for Chlorella strain not only increase in 
MUFAs but also PUFAs content. Polyunsaturated fatty acids are not good for biodiesel production. For different microalgae strains, the content of PUFAs ranges very widely from less than 3\% to almost $69 \%$ [56]. In the present study, the lowest content of PUFAs in the profile was found for C. vulgaris (38.71\%), the highest for O. submarina (47.75\%). Under nutrient-limited conditions in the culture, beneficial changes, i.e., decrease in PUFA content, were observed for both species of Chlorella and for O. submarina. The high content of PUFAs may increase nitrogen oxide emissions [86] from the biofuel although according to a study carried out by Wahlen et al. [90] biodiesel from the microalgae Chaetoceros gracilis had lower NOx emissions compared to conventional diesel. Low amount of PUFAs have a positive effect on the biodiesel flow properties, especially at low temperatures [81].

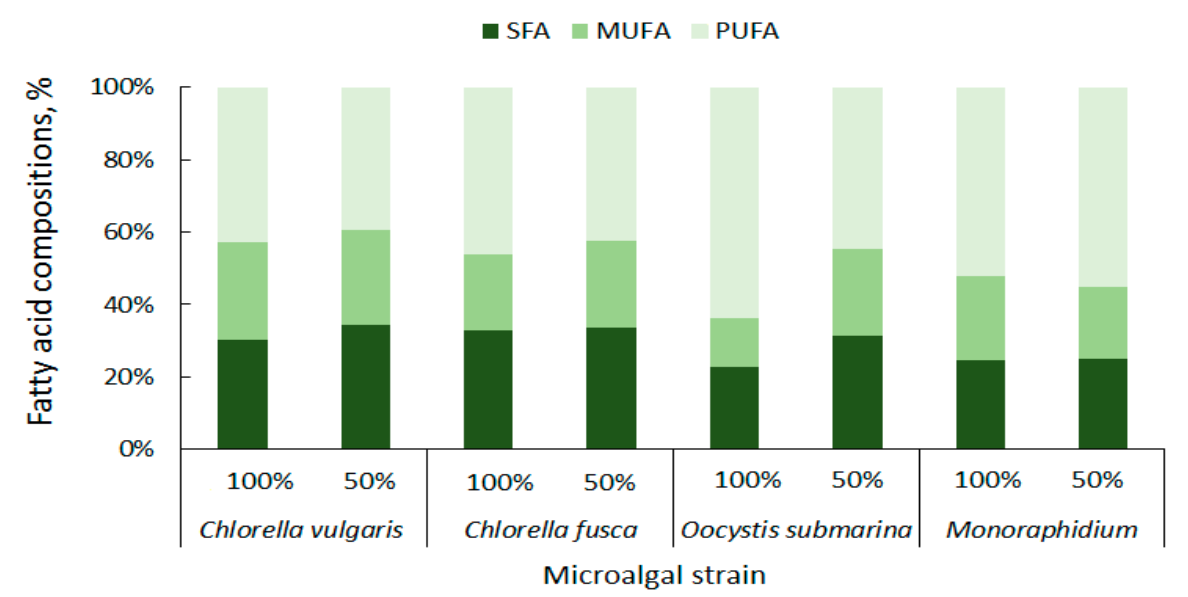

Figure 5. Summary composition of fatty acids in microalgal biomass.

\subsection{Biodiesel Properties}

Selected results from BiodieselAnalyzer@ Version 2.2 are shown in Table 2. In terms of energy, nutrient limitation was found to increase only the HHV values only for O. submarina and Monoraphidium. Lower nutrient dose decreased HHV for both Chlorella species. The best feedstock for biodiesel production was oil from C. vulgaris $100 \%, \mathrm{HHV}=35.483 \mathrm{MJ} \cdot \mathrm{kg}^{-1}$. The high energetic potential of Chlorella was also confirmed in a study carried out by Sakarika et al. [91], who compared energy efficiency of biodiesel, biomethane, and solid biofuel produced from the biomass of this microalgae species. Among the high-energy microalgae, Nannochloropsis sp. may be interesting, especially in countries with high insolation, as highlighted in the paper of Pradana et al. [92].

Table 2. Biodiesel fuel properties calculated on fatty acid profile.

\begin{tabular}{ccccccccc}
\hline \multirow{2}{*}{ Parameter } & \multicolumn{2}{c}{ Chlorella vulgaris } & \multicolumn{2}{c}{ Chlorella fusca } & \multicolumn{2}{c}{ Oocystis submarina } & \multicolumn{2}{c}{ Monoraphidium } \\
\cline { 2 - 8 } & $\mathbf{1 0 0} \%$ & $\mathbf{5 0} \%$ & $\mathbf{1 0 0} \%$ & $\mathbf{5 0 \%}$ & $\mathbf{1 0 0} \%$ & $\mathbf{5 0 \%}$ & $\mathbf{1 0 0} \%$ & $5 \mathbf{5 0}$ \\
\hline HHV & 35.483 & 34.495 & 34.353 & 33.328 & 29.467 & 32.979 & 30.157 & 31.831 \\
CN & 48.401 & 52.013 & 49.704 & 53.83 & 53.361 & 52.507 & 57.601 & 50.651 \\
D & 0.795 & 0.772 & 0.771 & 0.747 & 0.665 & 0.74 & 0.676 & 0.717 \\
KV & 3.076 & 3.008 & 2.93 & 2.876 & 2.422 & 2.808 & 2.593 & 2.636 \\
CFPP & 0.388 & -0.278 & -3.571 & -7.482 & -11.083 & -8.199 & -10.505 & -9.201 \\
OS & 5.975 & 6.408 & 5.82 & 5.872 & 5.212 & 5.994 & 5.536 & 5.799 \\
IV & 122.302 & 109.386 & 120.04 & 105.354 & 126.696 & 112.896 & 104.603 & 126.491 \\
\hline
\end{tabular}

HHV: Higher Heating Value $\left(\mathrm{MJ} \cdot \mathrm{kg}^{-1}\right)$, CN: Cetane number, D: Density $\left(\mathrm{g} \cdot \mathrm{cm}^{-3}\right), \mathrm{KV}$ : Kinematic Viscosity $\left(\mathrm{mm}^{2} \cdot \mathrm{s}^{-1}\right)$, CFPP: Cold Filter Plugging Point $\left({ }^{\circ} \mathrm{C}\right)$, OS: Oxidation Stability (h), IV: Iodine Value.

Nutrient stress increased the cetane number for Chlorella strains, in contrast to $O$. submarina and Monoraphidium. The highest value of this parameter was obtained for Monoraphidium $100 \%, \mathrm{CN}=57.601$. The $\mathrm{CN}$ value for oil of all tested microalgae species 
was high compared to the results presented by Yaşar et al. [93] for oils from oil crops cultivated for biodiesel production. The rheological parameters of biodiesel produced from microalgal biomass, such as density and kinematic viscosity, presented in Table 2, suggest that nutrient stress increased their values for O. submarina and Monoraphidium. The opposite dependence was found for Chlorella strains. The highest values were observed for C. vulgaris cultivated with full dose of nutrients (C.v.100\%). They were respectively $\mathrm{D}=0.795 \mathrm{~g} \cdot \mathrm{cm}^{-3}$ and $\mathrm{KV}=3.076 \mathrm{~mm}^{2} \cdot \mathrm{s}^{-1}$ and were most similar to the parameters of conventional diesel fuel $\left(\mathrm{D}=0.82-0.845 \mathrm{~g} \cdot \mathrm{cm}^{-3}\right.$ and $\left.\mathrm{KV}=2-4.5 \mathrm{~mm}^{2} \cdot \mathrm{s}^{-1}\right)$.

A significant parameter of biodiesel is the cold filter plugging point. The lowest and the most beneficial value of this parameter was obtained for O. submarina $(\mathrm{O} .100 \%)$, $\mathrm{CFPP}=-11.08^{\circ} \mathrm{C}$. Under nutrient stress conditions beneficial decrease in CFPP was observed only for Chlorella strains. The high oil content improves the CFPP index, therefore use of these microalgae is advantageous, especially when their cultivation is not competitive with food crops [94].

Oxidation stability, which indicates the formation of different types of sediments, resins, and acids in the fuel, increased for limited nutrient dose $(50 \%)$ and had the most beneficial value for $C$. vulgaris ( $\mathrm{OS}=6.41 \mathrm{~h}$ ). This is also confirmed by research carried out by Islam et al. [57].

Regarding iodine number IV, characterising the content of unsaturated compounds in biofuel, the $50 \%$ lower nutrient dose had a positive effect on this parameter except for Monoraphidium, which was characterised by the lowest value IV $=104.60$ at complete nutrient dose (100\%). In a study carried out by Islam et al. [57], the most beneficial value for this parameter was observed for Calothrix sp.

This study has shown that biodiesel produced from oil of different types of microalgae has some beneficial and some disadvantages. Other authors concluded the same [57]. The analysed parameters of biofuels produced from the investigated energy feedstocks do not provide their complete evaluation. According to a few studies carried out in this topic $[95,96]$, a complete evaluation of such energy feedstocks can be obtained only during engine tests. In these tests, not only energy parameters determination, but also emission of toxic components of exhaust gases can be evaluated, thus also environmental assessment of such biofuels.

Figure 6 shows results of carried out analysis with highlighting those microalgae species whose position is most close to the so-called decision axis. It is important to note that all highlights were microalgal strains under nutritional stress. It is concluded that nutrient stress in three out of four possible cases (except Monoraphidium), had a beneficial effect on the functional properties of the newly produced biodiesel. The ranking of microalgae strains, considering the culture conditions, is shown in Table 3.

Table 3. Ranking list of microalgae according to their suitability for biodiesel production.

\begin{tabular}{|c|c|c|c|c|}
\hline \multirow[t]{2}{*}{ Rank } & \multicolumn{2}{|c|}{ Microalgae Strains } & \multirow[t]{2}{*}{ F/2 Component Dose, $\%$} & \multirow[t]{2}{*}{ Phi } \\
\hline & Description & Name & & \\
\hline 1 & C.f. $50 \%$ & C. fusca & 50 & 0.1586 \\
\hline 2 & C.v.50\% & C. vulgaris & 50 & 0.1097 \\
\hline 3 & O.50\% & O. submarina & 50 & 0.0664 \\
\hline 4 & M.100\% & Monoraphidium & 100 & 0.0294 \\
\hline 5 & C.v.100\% & C. vulgaris & 100 & 0.0150 \\
\hline 6 & C.f.100\% & C. fusca & 100 & 0.0067 \\
\hline 7 & M.50\% & Monoraphidium & 50 & -0.1379 \\
\hline 8 & O.100\% & O. submarina & 100 & -0.2479 \\
\hline
\end{tabular}




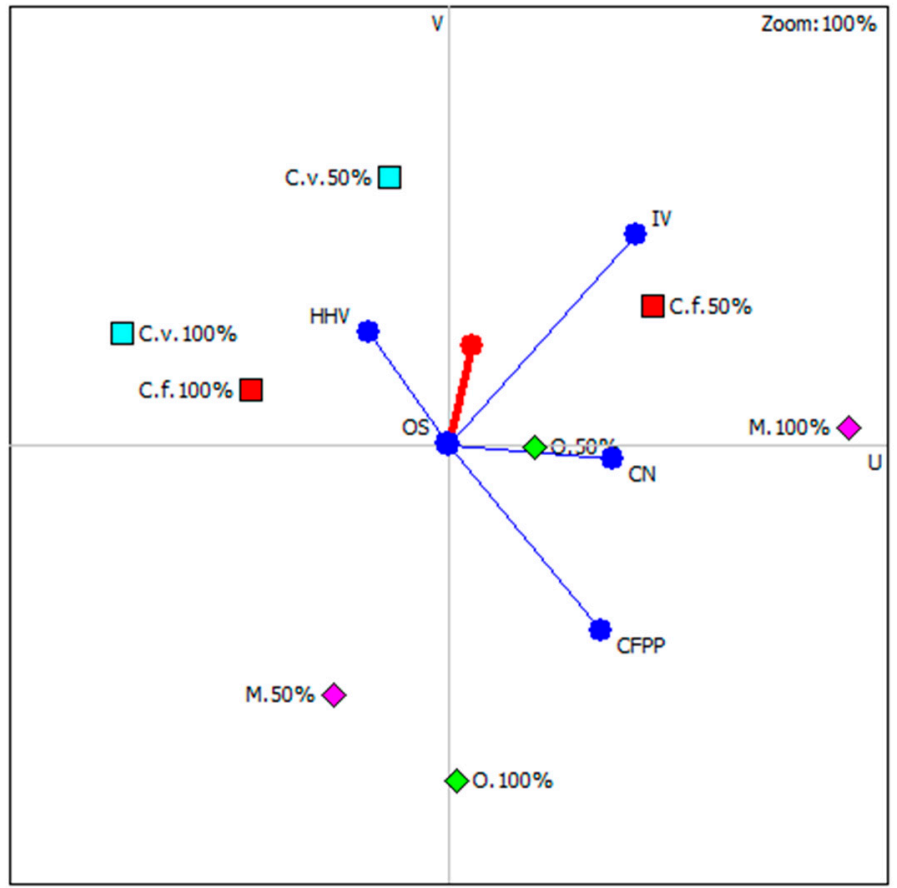

Figure 6. Graphical multi-criteria analysis PROMETHEE-GAIA (C.f.-C. fusca, C.v.-C. vulgaris, O.-O. submarina, M.-Monoraphidium).

\section{Conclusions}

Nutrient limitation $(50 \% \mathrm{~F} / 2)$ decreased microalgal biomass production, while beneficial changes were observed in ash and lipid content. The fatty acid profile of tested green microalgae strains indicates that these algae can be a source of feedstock for advanced biofuel production. Under nutritional stress conditions lipid enrichment in saturated fatty acids for C. vulgaris, O. submarina and Monoraphidium, and monounsaturated fatty acids for C. fusca and O. submarina was noted, which improves the biodiesel fuel properties. The fatty acid profile gives some information about the quality of microalgal biomass as an energy feedstock, but without engine tests, this assessment is not sufficient. However, according to carried out analysis, it can be concluded that nutrient limitation has a beneficial effect on the functional properties of biodiesel produced from oil of the tested microalgae. Positive changes were found for C. fusca, O. submarina and C. vulgaris.

Author Contributions: Conceptualization, M.H.-P.; methodology, M.H.-P., A.K., M.T. and A.G.; validation, M.H.-P., P.R., A.K., W.G., M.T. and A.G.; formal analysis, M.H.-P., P.R., A.K., M.T. and A.G.; investigation, M.H.-P., P.R., A.K., W.G., M.T. and A.G.; data curation, M.H.-P.; writing—original draft preparation, M.H.-P., P.R., A.K., M.T., A.G.; writing-review and editing, M.H.-P., P.R. and A.K.; visualization, M.H.-P., P.R. and A.K.; supervision, M.H.-P. All authors have read and agreed to the published version of the manuscript.

Funding: This research received no external funding.

Institutional Review Board Statement: Not applicable.

Informed Consent Statement: Not applicable.

Data Availability Statement: Not applicable.

Conflicts of Interest: The authors declare no conflict of interest. 


\section{References}

1. Man, K.L.; Lee, K.T. Microalgae biofuels: A critical review of issues, problems and the way forward. Biotechnol. Adv. 2012, 30, 679-690.

2. Goh, B.H.H.; Ong, H.C.; Cheah, M.Y.; Chen, W.H.; Yu, K.L.; Mahlia, T.M.I. Sustainability of direct biodiesel synthesis from microalgae biomass: A critical review. Renew. Sustain. Energy Rev. 2019, 107, 59-74. [CrossRef]

3. Dragone, G.; Fernandes, B.; Vicente, A.A.; Teixeira, J.A. Third generation biofuels from microalgae. In Current Research, Technology and Education Topics in Applied Microbiology and Microbial Biotechnology; Mendez-Vilas, A., Ed.; Formatex: Badajoz, Spain, 2010; pp. 1355-1366.

4. Ho, S.H.; Ye, X.; Hasunuma, T.; Chang, J.S.; Kondo, A. Perspectives on engineering strategies for improving biofuel production from microalgae-A critical review. Biotechnol. Adv. 2014, 32, 1448-1459. [CrossRef]

5. Brennan, L.; Owende, P. Biofuels from microalgae-A review of technologies for production, processing, and extractions of biofuels and co-products. Renew. Sustain. Energy Rev. 2010, 14, 557-577. [CrossRef]

6. Demirbas, A.; Demirbas, M.F. Importance of algae oil as a source of biodiesel. Energy Convers. Manag. 2011, 52, 163-170. [CrossRef]

7. Chew, K.W.; Yap, J.Y.; Show, P.L.; Suan, N.H.; Juan, J.C.; Ling, T.C.; Lee, D.J.; Chang, J.S. Microalgae biorefinery: High value products perspectives. Bioresour. Technol. 2017, 229, 53-62. [CrossRef]

8. Behera, S.; Singh, R.; Arora, R.; Sharma, N.K.; Shukla, M.; Kumar, S. Scope of algae as third generation biofuels. Front. Bioeng. Biotechnol. 2014, 2, 1-13. [CrossRef] [PubMed]

9. Hossain, N.; Mahlia, T.M.I.; Saidur, R. Latest development in microalgae-biofuel production with nano-additives. Biotechnol. Biofuels 2019, 12, 125. [CrossRef] [PubMed]

10. Mizik, T.; Gyarmati, G. Economic and Sustainability of Biodiesel Production-A Systematic Literature Review. Clean Technol. 2021, 3, 19-36. [CrossRef]

11. Wijffels, R.H. Potential of sponges and microalgae for marine biotechnology. Trends Biotechnol. 2008, 26, 26-31. [CrossRef]

12. Tu, R.; Jin, W.; Xi, T.; Yang, Q.; Han, S.; Abomohra, A. Effect of static magnetic field on the oxygen production of Scenedesmus obliquus cultivated in municipal wastewater. Water Res. 2015, 86, 132-138. [CrossRef]

13. Sun, X.M.; Ren, L.J.; Zhao, Q.Y.; Ji, X.J.; Huang, H. Microalgae for the production of lipid and carotenoids: A review with focus on stress regulation and adaptation. Biotechnol. Biofuels 2018, 11, 272. [CrossRef] [PubMed]

14. Demirbas, A. Use of algae as biofuel sources. Energy Convers. Manag. 2010, 51, 2738-2749. [CrossRef]

15. Singh, J.; Gu, S. Commercialization potential of microalgae for biofuels production. Renew. Sustain. Energy Rev. 2010, 14, 2596-2610. [CrossRef]

16. Chu, W.L. Strategies to enhance production of microalgal biomass and lipids for biofuel feedstock. Eur. J. Phycol. 2017, 52, 419-437. [CrossRef]

17. Fabris, M.; Abbriano, R.M.; Pernice, M.; Sutherland, D.L.; Commault, A.S.; Hall, C.C.; Labeeuw, L.; McCauley, J.I.; Kuzhiuparambil, U.; Ray, P.; et al. Emerging technologies in algal biotechnology: Toward the establishment of a sustainable, algae-based bioeconomy. Front. Plant Sci. 2020, 11, 279. [CrossRef] [PubMed]

18. Levasseur, W.; Perré, P.; Pozzobon, V. A review of high value-added molecules production by microalgae in light of the classification. Biotechnol. Adv. 2020, 41, 107545. [CrossRef] [PubMed]

19. Najafabadi, H.A.; Pazuki, G.; Vossoughi, M. Experimental study and thermodynamic modeling for purification of extracted algal lipids using an organic/aqueous two-phase system. RSC Adv. 2015, 5, 1153-1160. [CrossRef]

20. Duong, V.T.; Thomas-Hall, S.R.; Schenk, P.M. Growth and lipid accumulation of microalgae from fluctuating brackish and sea water locations in South East Queensland-Australia. Front. Plant Sci. 2015, 6, 359. [CrossRef]

21. Huerlimann, R.; de Nys, R.; Heimann, K. Growth, lipid content, productivity, and fatty acid composition of tropical microalgae for scale-up production. Biotechnol. Bioeng. 2010, 107, 245-257. [CrossRef] [PubMed]

22. Chisti, Y. Biodiesel from microalgae. Biotechnol. Adv. 2007, 25, 294-306. [CrossRef] [PubMed]

23. El Arroussi, H.; Benhima, R.; Bennis, I.; El Mernissi, N.; Wahby, I. Improvement of the potential of Dunaliella tertiolecta as a source of biodiesel by auxin treatment coupled to salt stress. Renew. Energy 2015, 77, 15-19. [CrossRef]

24. Sharma, P.K.; Saharia, M.; Srivastava, R.; Kumar, S.; Sahoo, L. Tailoring microalgae for efficient biofuel production. Front. Mar. Sci. 2018, 5, 1-18. [CrossRef]

25. Wahidin, S.; Idris, A.; Shaleh, S.R.M. The influence of light intensity and photoperiod on the growth and lipid content of microalgae Nannochloropsis sp. Bioresour. Technol. 2013, 129, 7-11. [CrossRef]

26. Rodolfi, L.; Zittelli, G.C.; Bassi, N.; Padovani, G.; Biondi, N.; Bonini, G.; Tredici, M.R. Microalgae for oil: Strain selection, induction of lipid synthesis and outdoor mass cultivation in a low-cost photobioreactor. Biotech. Bioeng. 2009, 102, 100-112. [CrossRef] [PubMed]

27. Chokshi, K.; Pancha, I.; Trivedi, K.; George, B.; Maurya, R.; Ghosh, A.; Mishra, S. Biofuel potential of the newly isolated microalgae Acutodesmus dimorphus under temperature induced oxidative stress conditions. Bioresour. Technol. 2015, 180, 162-171. [CrossRef] [PubMed]

28. Jiang, L.; Ji, Y.; Hu, W.; Pei, H.; Nie, C.; Ma, G.; Song, M. Adjusting irradiance to enhance growth and lipid production of Chlorella vulgaris cultivated with monosodium glutamate wastewater. J. Photochem. Photobiol. B Biol. 2016, 162, 619-624. [CrossRef] 
29. Hsieh, C.H.; Wu, W.T. Cultivation of microalgae for oil production with a cultivation strategy of urea limitation. Bioresour. Technol. 2009, 100, 3921-3926. [CrossRef]

30. Pancha, I.; Chokshi, K.; Maurya, R.; Trivedi, K. Salinity induced oxidative stress enhanced biofuel production potential of microalgae Scenedesmus sp. CCNM 1077. Bioresour. Technol. 2015, 189, 341-348. [CrossRef]

31. Damiani, M.C.; Popovich, C.A.; Constenla, D.; Leonardi, P.I. Lipid analysis in Haematococcus pluvialis to assess its potential use as a biodiesel feedstock. Bioresour. Technol. 2008, 99, 3389-3396. [CrossRef]

32. He, P.J.; Mao, B.; Shen, C.M.; Shao, L.M.; Lee, D.J.; Chang, J.S. Cultivation of Chlorella vulgaris on wastewater containing high levels of ammonia for biodiesel production. Bioresour. Technol. 2013, 129, 177-181. [CrossRef]

33. Su, Y.; Song, K.; Zhang, P.; Su, Y.; Cheng, J.; Chen, X. Progress of microalgae biofuel's commercialization. Renew. Sustain. Energy Rev. 2017, 74, 402-411. [CrossRef]

34. Sun, J.; Xiong, X.; Wang, M.; Du, H.; Li, J.; Zhou, D.; Zuo, J. Microalgae biodiesel production in China: A preliminary economic analysis. Renew. Sustain. Energy Rev. 2019, 104, 296-306. [CrossRef]

35. Knothe, G. Designer biodiesel: Optimizing fatty ester composition to improve fuel properties. Energy Fuels 2008, 22, 1358-1364. [CrossRef]

36. Hu, Q.; Sommerfeld, M.; Jarvis, E.; Ghirardi, M.; Posewitz, M.; Seibert, M.; Darzins, A. Microalgal triacyglycerols as feedstocks for biofuel production: Perspectives and advances. Plant J. 2008, 54, 621-639. [CrossRef] [PubMed]

37. Yang, M.; Fan, Y.; Wu, P.C.; Chu, Y.D.; Shen, P.L.; Xue, S.; Chi, Z.Y. An Extended Approach to Quantify Triacylglycerol in Microalgae by Characteristic Fatty Acids. Front. Plant Sci. 2017, 8, 1949. [CrossRef]

38. Maltsev, Y.; Maltseva, K. Fatty acids of microalgae: Diversity and applications. Rev. Environ. Sci. Biotechnol. 2021, 20, 515-547. [CrossRef]

39. Zhu, L.D.; Li, Z.H.; Hiltunen, E. Strategies for Lipid Production Improvement in Microalgae as a Biodiesel Feedstock. BioMed Res. Int. 2016, 2016, 8792548. [CrossRef] [PubMed]

40. Ramos, M.J.; Fernández, C.M.; Casas, A.; Rodríguez, L.; Pérez, Á. Influence of fatty acid composition of raw materials on biodiesel properties. Bioresour. Technol. 2009, 100, 261-268. [CrossRef]

41. Yusof, Y.A.M.; Basari, J.M.H.; Mukti, N.A.; Sabuddin, R.; Muda, A.R.; Sulaiman, S.; Makpol, S.; Ngah, W.Z.W. Fatty acids composition of microalgae Chlorella vulgaris can be modulated by varying carbon dioxide concentration in outdoor culture. Afr. J. Biotechnol. 2011, 10, 13536-13542.

42. Wan Afifudeen, C.L.; Loh, S.H.; Aziz, A.; Takahashi, K.; Effendy, A.W.M.; Cha, T.S. Double-high in palmitic and oleic acids accumulation in a non-model green microalga, Messastrum gracile SE-MC4 under nitrate-repletion and -starvation cultivations. Sci. Rep. 2021, 11, 381. [CrossRef] [PubMed]

43. Atadashi, I.M.; Aroua, M.K.; Aziz, A.A. High quality biodiesel and its diesel engine application: A review. Renew. Sustain. Energy Rev. 2010, 14, 1999-2008. [CrossRef]

44. Tat, M.E.; Gerpen, J.H.V. The specific gravity of biodiesel and its blends with diesel fuel. J. Am. Oil Chem. Soc. 2000, 77, 115-119. [CrossRef]

45. Dzida, M.; Prusakiewicz, P. The effect of temperature and pressure on the physicochemical properties of petroleum diesel oil and biodiesel fuel. Fuel 2008, 87, 1941-1948. [CrossRef]

46. De Torres, M.; Jiménez-Osés, G.; Mayoral, J.A.; Pires, E. Fatty acid derivatives and their use as CFPP additives in biodiesel. Bioresour. Technol. 2011, 102, 2590-2594. [CrossRef]

47. Kralova, I.; Sjoblom, J. Biofuels-renewable energy sources: A review. J. Dispers. Sci. Technol. 2010, 31, 409-425. [CrossRef]

48. Guillard, R.R.L.; Ryther, J.J. Studies of marine planktonic diatoms in Cyclotella nana Hustedt and Detonula confervacea Cleve. Can. J. Microbiol. 1962, 8, 229-239. [CrossRef] [PubMed]

49. Ratomski, P.; Hawrot-Paw, M. Production of Chlorella vulgaris biomass in tubular photobioreactors during different culture conditions. Appl. Sci. 2021, 11, 3106. [CrossRef]

50. Bligh, E.G.; Dyer, W.J. A rapid method of total lipid extraction and purification. Can. J. Biochem. Physiol. 1959, 37, 911-917. [CrossRef] [PubMed]

51. Polish Standards PN-EN ISO 18122:2016-01. Biopaliwa Stałe-Oznaczanie Zawartości Popiołu, 2016. Polish Committee for Standardisation. Available online: https:/ / sklep.pkn.pl/pn-en-iso-18122-2016-01p.html (accessed on 26 April 2021). (In Polish)

52. Folch, J.; Lees, M.; Stanley, G.S. A simple method for the isolation and purification of total lipids from animal tissues. J. Biol. Chem. 1957, 226, 497-509. [CrossRef]

53. AOCS. Official Methods and Recommended Practices of the American Oil Chemist's Society, 2nd ed.; American Oil Chemist's Society, AOACS Press: Champaign, IL, USA, 1997; pp. 1-2.

54. Ramírez-Verduzco, L.F.; Rodríguez-Rodríguez, J.E.; del Rayo Jaramillo-Jacob, A. Predicting cetane number, kinematic viscosity, density and higher heating value of biodiesel from its fatty acid methyl ester composition. Fuel 2012, 91, 102-111. [CrossRef]

55. Talebi, A.F.; Mohtashami, S.K.; Tabatabaei, M.; Tohidfar, M.; Bagheri, A.; Zeinalabedini, M.; Mirzaei, H.M.; Mirzajanzadeh, M.; Shafaroudi, S.M.; Bakhtiari, S. Fatty acids profiling: A selective criterion for screening microalgae strains for biodiesel production. Algal Res. 2013, 2, 258-267. [CrossRef]

56. Islam, M.A.; Magnusson, M.; Brown, R.J.; Ayoko, G.A.; Nabi, M.N.; Heimann, K. Microalgal Species Selection for Biodiesel Production Based on Fuel Properties Derived from Fatty Acid Profiles. Energies 2013, 6, 5676-5702. [CrossRef] 
57. Deshmukh, S.; Bala, K.; Kumar, R. Selection of microalgae species based on their lipid content, fatty acid profile and apparent fuel properties for biodiesel production. Environ. Sci. Pollut. Res. 2019, 26, 24462-24473. [CrossRef]

58. Zhao, Y.; Li, D.; Ding, K.; Che, R.; Xu, J.W.; Zhao, P.; Li, T.; Ma, H.; Yu, X. Production of biomass and lipids by the oleaginous microalgae Monoraphidium sp. QLY-1 through heterotrophic cultivation and photo-chemical modulator induction. Bioresour. Technol. 2016, 211, 669-676. [CrossRef]

59. Dhup, S.; Dhawan, V. Effect of nitrogen concentration on lipid productivity and fatty acid composition of Monoraphidium sp. Bioresour. Technol. 2014, 152, 572-575. [CrossRef] [PubMed]

60. Sacristán de Alva, M.; Luna-Pabello, V.M.; Cadena, E.; Ortiz, E. Green microalgae Scenedesmus acutus grown on municipal wastewater to couple nutrient removal with lipid accumulation for biodiesel production. Bioresour. Technol. 2013, 146, 744-748. [CrossRef] [PubMed]

61. Gigova, L.; Ivanova, N.J. Microalgae respond differently to nitrogen availability during culturing. J. Biosci. 2015, 40, 365-374. [CrossRef] [PubMed]

62. Kim, W.; Park, J.M.; Gim, G.H.; Jeong, S.H.; Kang, S.H.; Kang, C.M.; Kim, D.J.; Kim, S.W. Optimization of culture conditions and comparison of biomass productivity of three green algae. Bioprocess Biosyst. Eng. 2012, 35, 19-27. [CrossRef]

63. Griffiths, M.J.; Harrison, S.T. Lipid productivity as a key characteristic for choosing algal species for biodiesel production. J. Appl. Phycol. 2009, 21, 493-507. [CrossRef]

64. Klin, M.; Pniewski, F.; Latała, A. Characteristics of the growth rate and lipid production in fourteen strains of Baltic green microalgae. Oceanol. Hydrobiol. Stud. 2018, 47, 10-18. [CrossRef]

65. Procházková, G.; Brányiková, I.; Zachleder, V.; Brányik, T. Effect of nutrient supply status on biomass composition of eukaryotic green microalgae. J. Appl. Phycol. 2014, 26, 1359-1377. [CrossRef]

66. Singh, P.; Kumari, S.; Guldhe, A.; Misra, R.; Rawat, I.; Bux, F. Trends and novel strategies for enhancing lipid accumulation and quality in microalgae. Renew. Sustain. Energy Rev. 2016, 55, 1-16. [CrossRef]

67. Converti, A.; Casazza, A.A.; Ortiz, E.Y.; Perego, P.; Del Borghi, M. Effect of temperature and nitrogen concentration on the growth and lipid content of Nannochloropsis oculata and Chlorella vulgaris for biodiesel production. Chem. Eng. Process. 2009, 48, $1146-1151$. [CrossRef]

68. Ratomski, P.; Hawrot-Paw, M. Influence of Nutrient-Stress Conditions on Chlorella vulgaris Biomass Production and Lipid Content. Catalysts 2021, 11, 573. [CrossRef]

69. Kim, J.; Lingaraju, B.P.; Rheaume, R.; Lee, J.Y.; Siddiqui, K.F. Removal of ammonia from wastewater effluent by Chlorella vulgaris. Tsinghua Sci. Technol. 2010, 15, 391-396. [CrossRef]

70. Mata, T.M.; Martins, A.A.; Caetano, N.S. Microalgae for biodiesel production and other applications: A review. Renew. Sustain. Energy Rev. 2010, 14, 217-232. [CrossRef]

71. Vassilev, S.; Vassileva, C.; Vassilev, V. Advantages and disadvantages of composition and properties of biomass in comparison with coal: An overview. Fuel 2015, 158, 330-350. [CrossRef]

72. Vassilev, S.; Baxter, D.; Vassileva, C. An overview of the behaviour of biomass during combustion: Part II. Ash fusion and ash formation mechanisms of biomass types. Fuel 2014, 117, 152-183. [CrossRef]

73. Vardon, D.R.; Sharma, B.K.; Scott, J.; Yu, G.; Wang, Z.; Schideman, L.; Zhang, Y.; Strathmann, T.J. Chemical properties of biocrude oil from the hydrothermal li-quefaction of Spirulina algae, swine manure, and digested anaerobic sludge. Bioresour. Technol. 2011, 102, 8295-8303. [CrossRef] [PubMed]

74. Gai, C.; Zhang, Y.; Chen, W.T.; Zhang, P.; Dong, Y. Energy and nutrient recovery efficiencies in biocrude oil produced via hydrothermal liquefaction of Chlorella pyrenoidosa. RSC Adv. 2014, 4, 16958-16967. [CrossRef]

75. Bi, Z.; He, B.B. Characterization of microalgae for the purpose of biofuel production. Trans. ASABE 2013, 56, 1529-1539.

76. Roostaei, J.; Zhang, Y.; Gopalakrishnan, K.; Ochocki, A.J. Mixotrophic Microalgae Biofilm: A Novel Algae Cultivation Strategy for Improved Productivity and Cost-efficiency of Biofuel Feedstock Production. Sci. Rep. 2018, 8, 12528. [CrossRef] [PubMed]

77. Knothe, G. Improving biodiesel fuel properties by modifying fatty ester composition. Energy Environ. Sci. 2009, 2, 759-766. [CrossRef]

78. Lee, S.J.; Go, S.; Jeong, G.T.; Kim, S.K. Oil Production from Five Marine Microalgae for the Production of Biodiesel. Biotechnol. Bioproc. Eng. 2011, 16, 561-566. [CrossRef]

79. Teh, K.Y.; Loh, S.H.; Aziz, A.; Takahashi, K.; Effendy, A.W.M.; Cha, T.S. Lipid accumulation patterns and role of different fatty acid types towards mitigating salinity fluctuations in Chlorella vulgaris. Sci. Rep. 2021, 11, 438. [CrossRef] [PubMed]

80. Giakoumis, E.G.; Sarakatsanis, C.K.A. Comparative Assessment of Biodiesel Cetane Number Predictive Correlations Based on Fatty Acid Composition. Energies 2019, 12, 422. [CrossRef]

81. Morales, M.; Aflalo, C.; Bernard, O. Microalgal lipids: A review of lipids potential and quantification for 95 phytoplankton species. Biomass Bioenergy 2021, 150, 106108. [CrossRef]

82. Petkov, G.; Garcia, G. Which are fatty acids of the green alga Chlorella? Biochem. Syst. Ecol. 2007, 35, 281-285. [CrossRef]

83. Zhang, K.; Sun, B.; She, X.; Zhao, F.; Cao, Y.; Ren, D.; Lu, J. Lipid production and composition of fatty acids in Chlorella vulgaris cultured using different methods: Photoautotrophic, heterotrophic, and pure and mixed conditions. Ann. Microbiol. 2014, 64, 1239-1246. [CrossRef]

84. Da Costa, F.; Le Grand, F.; Quéré, C.; Bougaran, G.; Cadoret, J.P.; Robert, R.; Soudant, P. Effects of growth phase and nitrogen limitation on biochemical composition of two strains of Tisochrysis lutea. Algal Res. 2017, 27, 177-189. [CrossRef] 
85. Mostafa, S.S.M.; El-Gendy, N.S. Evaluation of fuel properties for microalgae Spirulina platensis biodiesel and its blends with Egyptian petro-diesel. Arab. J. Chem. 2017, 10, 2040-2050. [CrossRef]

86. Cao, Y.; Liu, W.; Xu, X.; Zhang, H.; Wang, J.; Xian, M. Production of free monounsaturated fatty acids by metabolically engineered Escherichia coli. Biotechnol. Biofuels 2014, 7, 1-11. [CrossRef]

87. Dahmen, I.; Chtourou, H.; Jebali, A.; Daassi, D.; Karray, F.; Hassairi, I.; Sayadi, S.; Abdelkafi, S.; Dhouib, A. Optimisation of the critical medium components for better growth of Picochlorum sp. and the role of stressful environments for higher lipid production. J. Sci. Food Agric. 2014, 94, 1628-1638. [CrossRef]

88. Arora, N.; Philippidis, G.P. Insights into the physiology of Chlorella vulgaris cultivated in sweet sorghum bagasse hydrolysate for sustainable algal biomass and lipid production. Sci. Rep. 2021, 11, 6779. [CrossRef] [PubMed]

89. Rohit, M.V.; Mohan, S.V. Quantum Yield and Fatty Acid Profile Variations with Nutritional Mode during Microalgae Cultivation. Front. Bioeng. Biotechnol. 2018, 6, 111. [CrossRef]

90. Wahlen, B.D.; Morgan, M.R.; McCurdy, A.T.; Willis, R.M.; Morgan, M.D.; Dye, D.J.; Bugbee, B.; Wood, B.D.; Seefeldt, L.C. Biodiesel from Microalgae, Yeast, and Bacteria: Engine Performance and Exhaust Emissions. Energy Fuel 2013, 27, 220-228. [CrossRef]

91. Sakarika, M.; Kornaros, M. Chlorella vulgaris as a green biofuel factory: Comparison between biodiesel, biogas and combustible biomass production. Bioresour. Technol. 2019, 273, 237-243. [CrossRef]

92. Pradana, Y.S.; Sudibyo, H.; Suyono, E.A.; Indarto; Budiman, A. Oil Algae Extraction of Selected Microalgae Species Grown in Monoculture and Mixed Cultures for Biodiesel Production. Energy Procedia 2017, 105, 277-282. [CrossRef]

93. Yaşar, F. Comparision of fuel properties of biodiesel fuels produced from different oils to determine the most suitable feedstock type. Fuel 2020, 264, 116817. [CrossRef]

94. Gouveia, L.; Oliveira, A.L. Microalgae as a raw material for biofuels production. J. Ind. Microbiol. Biotechnol. 2009, 36, 269-274. [CrossRef] [PubMed]

95. Mofijur, M.; Rasul, M.G.; Hassan, N.M.S.; Nabi, M.N. Recent Development in the Production of Third Generation Biodiesel from Microalgae. Energy Procedia 2019, 156, 53-58. [CrossRef]

96. Tayari, S.; Abedi, R.; Rahi, A. Comparative assessment of engine performance and emissions fueled with three different biodiesel generations. Renew. Energy 2020, 147, 1058-1069. [CrossRef] 